\title{
Hubungan Kemampuan Berpikir Reflektif Matematis dengan Kemampuan Pemecahan Masalah Matematis Peserta Didik
}

\author{
R.A. Annisa Cahya Imani Syadid ${ }^{1 *}$ \& Sugeng Sutiarso ${ }^{2}$ \\ 1,2 Universitas Lampung, Bandar Lampung, Indonesia
}

\section{INFO ARTICLES}

\section{Article History:}

Received: 29-05-2021

Revised: 30-06-2021

Approved: 30-06-2021

Publish Online: 30-06-2021

\section{Key Words:}

Mathematical Reflective Thinking Ability; Mathematical Problems Solving Ability;

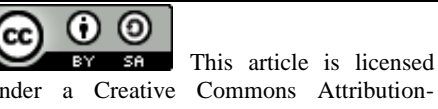
ShareAlike 4.0 International License.

\begin{abstract}
Mathematical reflective thinking skills and mathematical problem solving are abilities that must be developed by students because these abilities are needed when learning mathematics. The purpose of this study was to see the relationship between mathematical reflective thinking skills and mathematical problem solving. The type of this research is correlational design. The sampling technique used probability sampling with a research sample of 34 students of class XI SMK Muhammadiyah 2 Bandar Lampung. The data collection method for this research is a test of mathematical reflective thinking ability and a test of mathematical problems solving ability. The data analysis technique in this study is simple linear regression analysis. Based on the results of the study, it can be found that there is a relationship between mathematical reflective thinking skills and mathematical problem solving. The influence of mathematical reflective thinking ability on mathematical problem solving is $27 \%$.
\end{abstract}

\begin{abstract}
Abstrak: Kemampuan berpikir reflektif matematis dan pemecahan masalah matematis marupakan kemampuan yang harus dikembangkan peserta didik karena kemampuan ini sangat dibutuhkan ketika pembelajaran matematika. Tujuan penelitian ini untuk melihat hubungan antara kemampuan berpikir reflektif matematis dengan pemecahan masalah matematis. Jenis penelitian ini yaitu correlational design. Teknik pengambilan sampel menggunakan probability sampling dengan sampel penelitian sebanyak 34 peserta didik kelas XI SMK Muhammadiyah 2 Bandar Lampung. Metode pengumpulan data penelitian ini adalah tes kemampuan berpikir reflektif matematis dan tes kemampuan pemecahan masalah matematis. Teknik analisis data pada penelitian ini yaitu analisis regresi linier sederhana. Berdasarkan hasil penelitian dapat diperoleh bahwa terdapat hubungan antara kemampuan berpikir reflektif matematis dengan pemecahan masalah matematis. Besar pengaruh kemampuan berpikir reflektif matematis terhadap pemecahan masalah matematis yaitu sebesar $27 \%$.
\end{abstract}

Correspondence Address: Jl. Prof. Dr. Ir. Sumantri Brojonegoro, Bandar Lampung, Lampung, Indonesia, e-mail: raannisacahyaimani@gmail.com

How to Cite (APA $6^{\text {th }}$ Style): Syadid, R.A.C.I., \& Sutiarso, S. (2021). Hubungan Kemampuan Berpikir Reflektif Matematis dengan Kemampuan Pemecahan Masalah Matematis Peserta Didik. JKPM (Jurnal Kajian Pendidikan Matematika), 6(2): 327-336

Copyright: 2021 R.A. Annisa Cahya Imani Syadid, Sugeng Sutiarso

Competing Interests Disclosures: The authors declare that they have no significant competing financial, professional or personal interests that might have influenced the performance or presentation of the work described in this manuscript. 


\section{PENDAHULUAN}

Permasalahan dalam ilmu matematika dapat diselesaikan dengan kemampuan berpikir reflektif matematis, kemampuan ini diharapan membantu peserta didik guna menghadapi dan menyelesaikan masalah-masalah yang dihadapi dalam pembelajaran matematika (Betne, 2019; Noer et. al., 2020). Berpikir secara reflektif matematis dalam proses belajar dapat menentukan rancangan penyelesaian masalah dan memudahkan dalam menyimpulkan masalah secara tepat (Muzaimah \& Noer, 2019; Öztürk, 2020). Kemampuan berpikir reflektif matematis bertujuan untuk mengkaji lebih dalam, dan mengamati proses dari pencarian solusi untuk menyelesaikan masalah matematika (Kusuma et. al., 2020; Permatasari et. al., 2020).

Peserta didik diharapkan dapat mengembangkan kemampuan berpikir reflektif matematis saat melaksanakan proses belajar matematika, kemampuan berpikir reflektif matematis yang baik akan sebanding dengan kemampuan pemecahan masalah yang dimilikinya (Egmir \& Ocak, 2020; Mulyani et. al., 2020; Yasin et. al., 2020). Keterampilan pemecahan masalah dapat diasah dengan refleksi secara sistematis dan konseptual (Noer et. al., 2020; Syamsuddin, 2020). Kemampuan berpikir reflektif sangat di butuhkan guna mencari solusi, mengembangkan ide secara kreatif, memudahkan dalam menyelesaikan tugas, memudahkan dalam belajar, dan bertindak untuk membuat suatu keputusan, serta dapat mengasah keterampilan secara sistematis dan konseptual (Adha \& Rahaju, 2020; Sihaloho \& Zulkarnaen, 2019). Selain kemampuan berpikir reflektif matematis yang harus dikuasai, peserta didik juga perlu mengasah kemampuan pemecahan masalah matematis dalam proses pembelajaran khususnya pembelajaran matematika.

Kemampuan pemecahan masalah berguna untuk peserta didik dalam mengembangkan potensi dari keterampilan dan pengetahuan dalam menyelesaikan masalah pada lingkungan pendidikan maupun di lingkungan masyarakat (Badjiser et. al., 2019; Ernawati \& Sutiarso, 2020; Sari et. al., 2019). Kemampuan pemecahan masalah dinilai penting bagi peserta didik untuk menghadapi perkembangan zaman melalui kemajuan ilmu pengetahuan dan juga teknologi (Rohmah \& Sutiarso, 2018; Zahroh et. al., 2018), dan peserta diidk diharapan dapat berinteraksi sosial secara baik dengan masyarakat (Anggalia et. al., 2020). Melalui kemampuan pemecahan masalah matematis diharapkan peserta didik dapat menemukan konsep matematika yang dipelajari dan memahami penggunaan konsep tersebut dalam menyelesaikan masalah (Ernawati \& Sutiarso, 2020; Wahyuningtyas et. al., 2020). Kemampuan pemecahan masalah matematis memungkinkan peserta didik untuk dapat memecahkan masalah sehari-hari, belajar tentang ilmu rasional, terampil dalam mengaplikasikan matematika, dan memiliki kepercayaan diri dalam menyelesaikan masalah matematika (Akbar et al., 2020; Wijayanti et. al., 2019). Kesimpulannya bahwa kemampuan berpikir reflektif dan pemecahan masalah perlu dikuasai dan diasah dalam proses belajar matematika untuk menunjang proses belajar bagi peserta didik.

Berdasarkan dari hasil pra penelitian yang telah dilakukan peneliti di SMK Muhammadiyah 2 Bandar Lampung, diperoleh hasil wawancara dan observasi kepada salah satu pendidik matematika di kelas X yaitu masih rendahnya kemampuan berpikir reflektif matematis dan pemecahan masalah matematis peserta didik. Hal ini diperkuat dengan masih rendahnya tingkat ketuntasan belajar peserta didik terhadap pelajaran matematika. Terdapat beberapa faktor yang menyebabkan rendahnya kemampuan berpikir reflektif matematis dan pemecahan masalah matematis peserta didik diantaranya anggapan peserta didik bahwa belajar matematika menyulitkan untuk dipahami, rendahnya minat peserta didik belajar matematika, kurangnya variasi soal matematika yang mengaitkan dengan lingkungan sekitar, peserta didik juga belum secara optimal dapat menganalisis dan mengkomunikasikan permasalahan dengan baik untuk diselesaikan, hal tersebut disebabkan karena peserta didik sangat terpaku dengan contoh-contoh yang telah diberikan. Oleh sebab itu peneliti tertarik untuk meneliti tentang hubungan antara kemampuan berpikir reflektif matematis dan pemecahan masalah matematis peserta didik. 
Beberapa penelitian yang relevan tentang kemampuan berpikir reflektif matematis telah dilakukan oleh peneliti sebelumnya, diperoleh hasil bahwa terdapat peningkatan kemampuan berpikir reflektif matematis menggunakan model pembelajaran SSCS (Yasin et. al., 2020), dan kemampuan berpikir reflektif matematis mahasiswa dapat meningkat dengan berbantuan bahan ajar berbasis proyek (Amalia et. al., 2020). Kemudian penelitian relevan tentang kemampuan pemecahan masalah matematis telah dilakukan oleh peneliti sebelumnya, diperoleh hasil bahwa terdapat peningkatan kemampuan pemecahan masalah matematis melalui pendekatan Reciprocal Teaching (Akbar et. al., 2020), dan meningkatnya kemampuan pemecahan masalah matematis dengan penggunaan pembelajaran Problem Based Learning berbantuan Mind Mapping (Setiani \& Lukman, 2020).

Perbedaan penelitian tersebut dengan penelitian ini adalah akan meneliti hubungan kemampuan berpikir reflektif matematis dan kemampuan pemecahan masalah matematis peserta didik. Berdasarkan kajian tersebut, peneliti tertarik untuk melakukan penelitian dengan tujuan untuk melihat hubungan antara kemampuan berpikir reflektif matematis dengan kemampuan pemecahan masalah matematis peserta didik.

\section{METODE}

Jenis penelitian adalah kuantitatif dengan desain penelitian korelasional (Creswell, 2017). Penelitian kuantitatif merupakan penelitian tersusun secara sistematis, yang diterapkan pada penelitian ini untuk meneliti populasi dan sampel yang bersifat kategoris. Tujuan dari penelitian ini untuk mengetahui hubungan antara kemampuan berpikir reflektif dan pemecahan masalah matematis peserta didik. Adapun rancangan pada penelitian disajikan dalam Gambar 1.

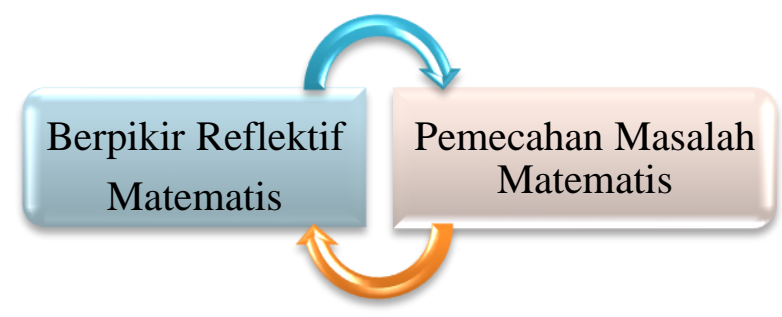

\section{Gambar 1. Rancangan Penelitian}

Penelitian ini menggunakkan sampel pada kelas XI SMK Muhammadiyah 2 Bandar Lampung. Teknik sampling yang digunakan adalah probability sampling. Sampel yang digunakan dalam penelitian ini adalah sebanyak 34 peserta didik kelas XI SMK Muhammadiyah 2 Bandar Lampung. Teknik pengumpulan data dalam penelitian ini menggunakan teknik dokumentasi dan tes. Penelitian ini menggunakan instrumen tes kemampuan berpikir reflektif dan tes kemampuan pemecahan masalah matematis. Penelitian korelasional yang digunakan dalam penelitian ini akan mendapatkan data berupa angka yang akan dianalisis menggunakan analisis Regresi Linear Sederhana sehingga mempermudah peneliti untuk menganalisis data yang telah diperoleh. Adapun analisis data yang digunakan pada penelitian ini diantaranya, uji normalitas, uji linieritas, uji auto korelasi, uji multikolinearitas, uji heterokedastisitas, uji regresi linier sederhana, uji koefisien determinasi $\left(R^{2}\right)$, dan uji $\mathrm{F}$

\section{HASIL}

Pengambilan data tes berpikir reflektif matematis dan tes pemecahan masalah matematis dilakukan pada sampel penelitian yaitu sebanyak 34 peserta didik kelas XI. Kemudian data nilai yang telah diperoleh selanjutnya diurutkan guna melihat nilai tertinggi $\left(X_{\text {maks }}\right)$ dan terendah $\left(X_{\text {min }}\right)$. Tahap selanjutnya mencari ukuran tendensi sentral yang diantaranya rataan $(\bar{x})$, median $\left(M_{e}\right)$, dan modus 
$\left(M_{0}\right)$. Selanjutnya mencari ukuran variasi kelompok yaitu jangkauan $(R)$ dan simpang baku $(S d)$. Adapun deskripsi data dapat dilihat pada Tabel 1.

Tabel 1. Deskripsi Data Berpikir Reflektif Matematis dan Pemecahan Masalah

\begin{tabular}{lccccccc}
\hline \multirow{1}{*}{ Data } & \multirow{2}{*}{$\mathrm{X}_{\max }$} & \multirow{2}{*}{$\mathrm{X}_{\min }$} & \multicolumn{2}{c}{ Ukuran Terdensi } & \multicolumn{2}{c}{ Ukuran Variansi } \\
& & & $\overline{\mathrm{x}}$ & $\mathrm{M}_{\mathrm{o}}$ & $\mathrm{M}_{\mathrm{e}}$ & $\mathrm{R}$ & $\mathrm{Sd}$ \\
\hline Berpikir Reflektif & 91,67 & 54,17 & 75,00 & 70,83 & 75,00 & 37,50 & 8,14 \\
Pemecahan Masalah & 93,75 & 56,25 & 78,68 & 75,00 & 81,25 & 37,50 & 11,00 \\
\hline
\end{tabular}

Sumber: diolah dari data penelitian

Berdasarkan Tabel 1., hasil berpikir reflektif matematis diperoleh nilai max sebesar 91,67 dan min sebesar 54,17, selanjutnya hasil pemecahan masalah matematis diperoleh max sebesar 93,75. Dan min sebesar 56,25. Kemudian rata-rata nilai, median dan modus pada hasil berpikir reflektif matematis masing-masing sebesar 75,00,70,83, dan 75,00, rata-rata nilai, median dan modus pada hasil pemecahan masalah matematis masing-masing sebesar 78,68, 75,00, dan 81,25. Kesimpulannya bahwa hasil pemecahan masalah matematis sedikit lebih tinggi dari hasil berpikir reflektif matematis.

Langkah berikutnya, data yang diperoleh peneliti selanjutnya akan dianalisis. Salah satu cara yang yang dilakukan guna memperkuat hasil pengujian hipotesis penelitian yaitu dengan melakukan analisis data. Langkah pertama akan dilakukan uji normalitas berupa Kolmogorov Smirnov pada hasil kemampuan numerik peserta didik pada sampel penelitian. Keputusan uji dalam uji normalitas Kolmogorov Smirnov yaitu apabila nilai $p-$ value $>a=0,05$, maka diperoleh hasil bahwa data berdistribusi normal. Berikut ini hasil uji normalitas kelompok data dapat dilihat pada tabel 2 :

Tabel 2. Hasil Uji Normalitas

\begin{tabular}{lccc}
\hline \multicolumn{1}{c}{ Data } & $p-$ Value & Signifikansi & Keputusan \\
\hline Berpikir Reflektif & 0,107 & 0,05 & Beristribusi Normal \\
Pemecahan Masalah & 0,081 & 0,05 & Beristribusi Normal \\
\hline
\end{tabular}

Sumber: diolah dari data penelitian

Berdasarkan hasil pada Tabel 2., perhitungan uji normalitas terhadap hasil tes kemampuan berpikir reflektif dan pemecahan masalah matematis pada signifikansi $a=5 \%$ disimpulkan bahwa data penelitian tersebut merupakan populasi yang berdistribusi normal karena masuk kedalam kriteria bersitribus normal yaitu nilai $p-$ Value $>\alpha$.

Selanjutnya akan dilakukan uji linearitas dilakukan untuk melihat secara signifikan linier atau tidaknya data dalam penelitian tersebut. Uji linearitas digunakan untuk uji prasyarat dalam analisis regresi linier sederhana. Berikut hasil uji linearitas data disajikan dalam Tabel 3.

Tabel 3. Hasil Uji Linearitas

\begin{tabular}{cccc}
\hline Data & $p-$ Value & Signifikansi & Keputusan \\
\hline Berpikir Reflektif * Pemecahan Masalah & 0,875 & 0,05 & Linear \\
\hline
\end{tabular}

Sumber: diolah dari data penelitian

Berdasarkan Tabel 3., dapat disimpulkan bahwa data pada tabel tersebut terdapat hubungan yang linear antara kemampuan berpikir reflektif dan pemecahan masalah matematis karena sesuai dengan kriteria dimana $p-$ Value $=0,875>0,05$.

Berikutnya uji multikolinearitas dilakukan untuk melihat adakah hunungan antara variabel dependen pada model regresi tersebut. Jika tidak terdapat hubungan, maka disimpulkan tidak terjadinya multikolinearitas. Uji multikolinearitas dilakukan pada data nilai kemampuan berpikir reflektif terhadap pemecahan masalah matematis. Besaran dari Variance Inflation Factor (VIF) dan Tolerance bertujuan untuk melihat apakah terjadi multikolinieritas atau tidak. Tabel 4. merupakan hasil perhitungan uji multikolinearitas. 
Tabel 4. Hasil Uji Multikolinearitas

\begin{tabular}{ccc}
\hline Data & Tolerance & VIF \\
\hline Berpikir Reflektif Matematis & 1,000 & 1,000 \\
Dependent Variable: Pemecahan Masalah Matematis & \\
\hline
\end{tabular}

Sumber: diolah dari data penelitian

Berdasarkan Tabel 4., dapat disimpulkan bahwa data berpikir reflektif matematis tidak terjadi multikolinearitas karena nilai Tolerance berpikir reflektif matematis $=1,000>0,10$ dan juga nilai VIF (berpikir reflektif matematis $=1,000<10$.

Tujuan dari melakukan uji heterokedastisitas yaitu guna mengetahui apakah terdapat ketidaksamaan antara varian dan residual dari satu amatan dengan amatan lain yang disebut dengan heterokedastisitas. Penelitian ini menggunakan metode pengujian heterokedastisitas yaitu uji Glejser. Hasil perhitungan uji homogenitas adalah sebagai berikut:

Tabel 5. Uji Heterokedastisitas

\begin{tabular}{ccc}
\hline \multicolumn{1}{c}{ Data } & $\boldsymbol{p}-$ Value & Signifikansi \\
\hline Berpikir Reflektif Matematis & 0,427 & 0,05 \\
Dependent Variable: Abs_Res & & \\
\hline
\end{tabular}

Sumber: diolah dari data penelitian

Berdasarkan Tabel 5., hasil perhitungan dengan taraf signifikansi $\alpha=5 \%$ pada variabel berpikir reflektif matematis diperoleh nilai $p$-value $=0,427$. Artinya nilai $p-$ value $>\alpha=$ 0,05 , dan kesimpulannya tidak terjadi heteroskedastisitas.

Uji autokorelasi dipakai guna mengetahui adakah korelasi antara variabel yang telah diurutkan berdasarkan adanya perubahan terhadap waktu, sehingga terdapat suatu data yang dipengaruhi oleh data yang ada sebelumnya. Uji autokorelasi yang digunakan yaitu Uji Durbin Waston. Hasil perhitungan uji autokorelasi dapat dilihat dalam Tabel 6.

Tabel 6. Uji Autokorelasi

\begin{tabular}{cc}
\hline Statistik & Hasil Data \\
\hline $\mathrm{dU}$ & 1,5136 \\
Durbin Watson & 2,056 \\
$4-\mathrm{dU}$ & 2,4864 \\
Kesimpulan & $1,5136<2,056<2,4864$ \\
\hline
\end{tabular}

Sumber: diolah dari data penelitian

Berdasarkan Tabel 6., hasil perhitungan dengan signifikansi $\alpha=5 \%, k=1$, dan $N=34$, maka hasilnya yaitu $\mathrm{dU}(\mathrm{k}=1, \mathrm{~N}=34)<$ Durbin Watson $<4-\mathrm{dU}, 1,5136<2,056<2,4864$. Karena nilai Durbin Watson sebesar 2,056 berada pada $d U(1,5136)$ dan $4-d U(2,4864)$, dapat ditarik kesimpulan bahwa tidak terjadinya autokorelasi.

Analisis Regresi Linier Sederhana bertujuan untuk melihat hubungan linier antara variabel bebas dan variable terikat Perhitungan uji Regresi Linear Sederhana berbantuan aplikasi SPSS, yaitu untuk mengetahui hubungan kemampuan berpikir reflektif dengan pemecahan masalah matematis peserta didik. Hasil analisis Regresi Linear Sederhana menggunakan program SPSS, model persamaan Regresi Linear Sederhana diperoleh, kemudian ditampilkan dalam Tabel 7. 
Tabel 7. Analisis Regresi Linear Sederhana

\begin{tabular}{|c|c|c|c|c|c|}
\hline \multicolumn{6}{|c|}{ Coefficients $^{a}$} \\
\hline \multirow[b]{2}{*}{ Model } & \multicolumn{2}{|c|}{$\begin{array}{c}\text { Unstandardized } \\
\text { Coefficients }\end{array}$} & \multirow{2}{*}{$\begin{array}{c}\text { Standardized } \\
\text { Coefficients } \\
\text { Beta }\end{array}$} & \multirow[t]{2}{*}{$\mathrm{t}$} & \multirow[t]{2}{*}{ Sig. } \\
\hline & $\mathrm{B}$ & Std. Error & & & \\
\hline 1 (Constant) & 25,997 & 15,391 & & 1,689 & , 101 \\
\hline Berpikir Reflektif Matematis & ,702 & ,204 & ,520 & 3,442 &, 002 \\
\hline a. Dependent Variable: Pemecah & an Masa & h Matema & & & \\
\hline
\end{tabular}

Sumber: diolah dari data penelitian

Berdasarkan Tabel 7. , memperoleh model persamaan regresi linier sederhana yaitu:

$$
\hat{Y}=25,997+0,702 X
$$

Nilai konstanta pada persamaan diatas diperoleh sebesar 25,997 hal tersebut menunjukkan bahwa jika tidak terjadi kenaikan pada kemampuan pemecahan masalah, maka kemampuan berpikir reflektif matematis diperoleh sebesar 25,997. Koefisien regresi yaitu 0,702, hal tersebut memperlihatkan yaitu jika terjadi penambahan sebesar 1 angka pada pemecahan masalah, maka berpikir reflektif matematis akan mengalami kenaikan sebesar 0,702.

Uji yang dilakukkan selanjutnya yaitu uji koefisien determinasi $\left(R^{2}\right)$, dimana uji ini bertujuan melihat seberapa bersar kemampuan berpikir reflektif matematis dapat menerangkan variasi kemampuan pemecahan masalah matematis. Nilai dari koefisien determinasi yaitu berada pada nol dari satu. Hasil perhitungan koefisien determinasi $\left(R^{2}\right)$ yaitu:

Tabel 8. Hasil Koefisien Determinasi $\left(R^{2}\right)$

\begin{tabular}{|c|c|c|c|c|}
\hline \multicolumn{5}{|c|}{ Model Summary } \\
\hline Model & $\mathrm{R}$ & R Square & Adjusted R Square & $\begin{array}{l}\text { Std. Error of the } \\
\text { Estimate }\end{array}$ \\
\hline 1 &, $520^{\mathrm{a}}$ & ,270 & ,247 & 9,54336 \\
\hline $\begin{array}{l}\text { a. Predi } \\
\text { Model }\end{array}$ & $\begin{array}{l}r s:(C o \\
\text { mmary }\end{array}$ & $\begin{array}{l}\text { nstant), Ber } \\
b\end{array}$ & pikir Reflektif Matem & hatis \\
\hline
\end{tabular}

Berdasarkan Tabel 8., diperoleh hasil yaitu uji koefisien determinasi $\left(R^{2}\right)$ sebesar 0,270, dapat ditarik kesimpulan bahwa besarnya pengaruh kemampuan berpikir reflektif terhadap pemecahan masalah matematis yaitu $27 \%$.

Uji selanjutnya dalam penelitian ini menggunakan Uji F, uji ini berguna untuk melihat pengaruh variabel $X$ terhadap variabel $Y$. Hasil dari uji $\mathrm{F}$ dalam analisis Regresi Linear Sederhana selengkapnya dalam Tabel 9.

Tabel 9. Hasil Uji F dalam Analisis Regresi Linear Sederhana

\begin{tabular}{|c|c|c|c|c|c|}
\hline \multicolumn{6}{|c|}{ ANOVA $^{\mathrm{a}}$} \\
\hline Model & Sum of Squares & df & Mean Square & $\mathrm{F}$ & Sig. \\
\hline $1 \quad$ Regression & 1079,144 & 1 & 1079,144 & 11,849 &, $002^{\mathrm{b}}$ \\
\hline Residual & 2914,422 & 32 & 91,076 & & \\
\hline Total & 3993,566 & 33 & & & \\
\hline $\begin{array}{l}\text { a. Dependent Va } \\
\text { b. Predictors: }(C\end{array}$ & $\begin{array}{l}\text { iable: Pemecahan } \\
\text { onstant), Berpikir }\end{array}$ & $\begin{array}{l}\text { Masa } \\
\text { Reflel }\end{array}$ & $\begin{array}{l}\text { lah Matematis } \\
\text { ktif Matematis }\end{array}$ & & \\
\hline
\end{tabular}

Sumber: diolah dari data penelitian

Berdasarkan hasil pada Tabel 9., terlihat bahwa nilai $p$ - value diperoleh sebesar 0,002 untuk melihat hubungan berpikir reflektif terhadap pemecahan masalah matematis pada taraf signifikansi $a=5 \%$. Hasil tersebut menunjukkan $p-$ Value $<0,05$, hal tersebut memperoleh kesimpulan $H_{0}$ 
ditolak maka $H_{1}$ diterima. Dari hasil tersebut dapat ditarik kesimpulan bahwa terdapat hubungan kemampuan berpikir reflektif terhadap pemecahan masalah matematis.

\section{PEMBAHASAN}

Berdasarkan hasil penelitian yang diperoleh oleh peneliti, maka dapat disimpulkan bahwa terdapat hubungan kemampuan berpikir reflektif matematis dengan kemampuan pemecahan masalah matematis peserta didik. Hal tersebut dapat terjadi dikarenakan kemampuan berikir reflektif matematis dapat berpengaruh secara signifikan terhadap kemampuan pemecahan masalah matematis peserta didik.

Hasil penelitian yang diperoleh peneliti memiliki hubungan dengan hasil penelitian sebelumnya yang telah dilakukan oleh Suryana dan Nurrahmah, yaitu terdapat pengaruh model pembelajaran Guided Discovery Learning terhadap kemampuan berpikir reflektif peserta didik (Suryana \& Nurrahmah, 2020). Selanjutnya penelitian yang dilakukan Thahir et al., memperoleh hasil yaitu pembelajaran menggunakan model pembelajaran MURDER dan self efficacy dapat meningkatkan kemampuan berpikir reflektif peserta didik (Thahir et. al., 2019). Selanjutnya penelitian yang dilakukan oleh Ginanjar dan Widayanti, yaitu model pembelajaran Multiliterasi dapat meningkatkan kemampuan pemecahan masalah matematis peserta didik (Ginanjar \& Widayanti, 2019).dan penelitian yang dilakukan oleh Dewi et. al., yaitu terdapat pengaruh model pembelajaran Tutor Sebaya berbantuan komik matematika terhadap kemampuan pemecahan masalah peserta didik (Dewi et. al., 2020). Beberapa penelitian tersebut hanya terfokus pada satu kemampuan matematika (Rohmah \& Sutiarso, 2018). Kelebihan dari penelitian ini jika dibandingkan penelitian tersebut adalah peneliti tidak hanya terfokus kepada meneliti satu kemampuan saja, akan tetapi pada penelitian ini akan meneliti tentang hubungan kemampuan berpikir reflektif dengan kemampuan pemecahan masalah matematis.

Hasil analisis statistik secara umum menghasilkan nilai kemampuan berpikir reflektif matematis dan kemampuan pemecahan masalah matematis peserta didik juga tergolong cukup baik. Akan tetapi merujuk pada hasil yang telah diperoleh, masih terdapat beberapa peserta didik yang belum menguasai kemampuan berpikir reflektif dan kemampuan pemecahan masalah matematis dengan baik. Oleh karena itu perlu ditingkatkannnya lagi kemampuan berpikir reflektif dengan kemampuan pemecahan masalah matematis tersebut. Melalui hasil tersebut, pendidik diharapkan dapat memberikan solusi terbaik dalam mengasah dan meningkatkan kemampuan berpikir reflektif matematis dan kemampuan pemecahan masalah matematis peserta didik. Permasalahan ini perlu mendapat perhatian yang sungguh-sungguh mengingat peranan matematika yang begitu penting (Adha \& Rahaju, 2020). Pendidik perlu menerapkan strategi, metode, pendekatan, dan model pembelajaran yang dapat mengasah kemampuan berpikir reflektif dengan kemampuan pemecahan masalah matematis untuk menjadi lebih baik lagi (Halim et. al., 2021; Hwang \& Oh, 2021).

Hasil analisis Regresi Linear Sederhana menunjukkan bahwa berpikir reflektif matematis berpengaruh positif terhadap kemampuan pemecahan masalah matematis peserta didik menghasilkan nilai koefisien determinasi 27,0\%, berarti bahwa kemampuan pemecahan masalah matematis dapat ditentukan sebesar $27,0 \%$, oleh berpikir reflektif matematis, dengan catatan variabel-variabel lain tidak dilihat pengaruhnya. Implikasinya adalah dengan kemampuan berpikir reflektif matematis yang tergolong rata-rata tersebut, maka pengaruh positifnya adalah menjadikan kemampuan pemecahan masalah matematis matematika peserta didik juga tergolong rata-rata.

Berdasarkan hasil analisis Regresi Linear Sederhana menggunakan uji F, yaitu terdapat hubungan antara kemampuan berpikir reflektif matematis dengan kemampuan kemampuan pemecahan masalah matematis peserta didik. Artinya kemampuan pemecahan masalah matematis dengan kemampuan berpikir reflektif matematis peserta didik memiliki keselarasan (Sari et. al., 2019). Dalam penelitian ini dapat dilihat hasil nyata dari kemampuan pemecahan masalah matematis dan kemampuan berpikir reflektif matematis didik di sekolah. jika kemampuan pemecahan masalah 
matematis mengalami peningkatan, maka kemampuan berpikir reflektif matematis juga akan mengalami peningkatan dan begitupun sebaliknya (Palanisamy et. al., 2021). Kemampuan pemecahan masalah matematis dan kemampuan berpikir reflektif matematis berperan penting untuk dikuasai peserta didik, karena kemampuan tersebut dapat menunjang peserta didik dalam belajar dan menyelesaikan berbagai permasalahan matematika (Badjiser et. al., 2019; Noviyanti et. al., 2021).

Model persamaan regresi linier sederhana yang didapatkan pada penelitian ini yaitu $\hat{Y}=$ $25,997+0,702 X$. Berdasarkan hasil tersebut dapat diartikan bahwa nilai kostanta 25,997 menunjukkan bahwa jika tidak terdapat kenaikan kemampuan pemecahan masalah matematis, maka berpikir reflektif matematis akan mencapai 25,997. Nilai 0,702 merupakan koefisien regresi yang memiliki arti setiap ada penambahan 1 angka untuk kemampuan pemecahan masalah matematis, maka akan terdapat kenaikan berpikir reflektif matematis sebesar 0,702.

\section{SIMPULAN}

Berdasarkan hasil penelitian dan pembahasan dalam penelitian ini, maka dapat disimpulkan bahwa terdapat hubungan antara berpikir reflektif matematis dengan kemampuan pemecahan masalah matematis peserta didik. Besar pengaruh kemampuan berpikir reflektif matematis terhadap kemampuan pemecahan masalah matematis yaitu sebesar $27,0 \%$.

Peneliti mengharapkan kepada peneliti selanjutnya yang ingin meneliti tentang hubungan kemampuan berpikir reflektif matematis dengan kemampuan pemecahan masalah matematis peserta didik, hendaknya dapat diperluas dan dapat memilih sampel penelitian yang lebih banyak lagi. Hal tersebut bertujuan untuk melihat tingkat keefektifan dalam meneliti hubungan kemampuan berpikir reflektif matematis dengan kemampuan pemecahan masalah matematis peserta didik.

\section{DAFTAR RUJUKAN}

Adha, S. M., \& Rahaju, E. B. (2020). Profil Berpikir Reflektif Siswa Sma Dalam Memecahkan Masalah Matematika Ditinjau Dari Kecerdasan Logis-Matematis. Jurnal Penelitian Pendidikan Matematika dan Sains, 4(2), 61-71.

Akbar, P., Handayani, D., \& Mirza, A. (2020). Peningkatan Kemampuan Pemecahan Masalah Matematik Siswa Kelas 12 Pada Materi Dimensi Tiga Melalui Pendekatan Reciprocal Teaching. Jurnal Cendekia: Jurnal Pendidikan Matematika, 4(2), 900-913. https://doi.org/10.31004/cendekia.v4i2.330

Amalia, R., Zaki, M., \& Agustin, T. S. (2020). Analisis Kemampuan Berpikir Reflektif Matematis Mahasiswa Melalui Bahan Ajar Berbasis Proyek Pada Materi Dimensi Tiga. Jurnal Dimensi Matematika, 3(01), 172-181. https://doi.org/10.33059/jdm.v3i01.2454

Anggalia, F., Bharata, H., \& Rosidin, U. (2020). Developing PBL to improve mathematical problem solving and self efficacy. International Journal of Trends in Mathematics Education Research, 3(1), 24-30. https://doi.org/10.33122/ijtmer.v3i1.129

Badjiser, N. L., Suratno, J., \& Angkotasan, N. (2019). Kemampuan Berpikir Reflektif Matematis Siswa Dalam Menyelesaikan Soal Program Linear Di Sma Negeri 4 Kota Ternate. Jurnal Pendidikan Guru Matematika, 53(9), 1689-1699. www.journal.uta45jakarta.ac.id

Betne, P. (2019). Reflection as a learning tool in matematics. Transit: The LaGuardia Journal; on Teaching and learning, 4, 92-101.

Creswell, J. W. (2017). Research Design Pendekatan Metode Kualitatif, Kuantitatif, dan Campuran. (2 ed.). Yogyakarta: Pustaka Pelajar.

Dewi, P. A. C., Sudiarta, I. G. P., \& Suweken, G. (2020). Pengembangan Perangkat Model Pembelajaran Tutor Sebaya Berbantuan Komik Matematika untuk Meningkatkan Kemampuan Pemecahan Masalah Matematika Siswa. Jurnal Matematika, Sains, dan Pembelajarannya, 14(1), 106-118. 
Egmir, E., \& Ocak, I. (2020). The Relationship between Teacher Candidates' Critical Thinking Standards and Reflective Thinking Skills. International Journal of Progressive Education, 16(3), 156-170. https://doi.org/10.29329/ijpe.2020.248.12

Ernawati, \& Sutiarso, S. (2020). Analisis Kesulitan Menyelesaikan Soal Matematika Kategori Higher Order Thinking SkillS. Jurnal Penelitian Pembelajaran Matematika, 13(2), 178-195.

Ginanjar, A. Y., \& Widayanti, W. (2019). Penerapan Model Pembelajaran Multiliterasi Untuk Meningkatkan Kemampuan Literasi Matematis Siswa Di Sd/Mi. Primary: Jurnal Keilmuan dan Kependidikan Dasar, 10(2), 117-124. https://doi.org/10.32678/primary.v10i02.1283

Halim, A., Susanna, Evendi, Yusrizal, Musdar, \& Irwandi, I. (2021). The impact of the problembased instruction model on the students' problem solving ability. AIP Conference Proceedings, 2330, 1-9. https://doi.org/10.1063/5.0043124

Hwang, Y., \& Oh, J. (2021). The relationship between self-directed learning and problem-solving ability: The mediating role of academic self-efficacy and self-regulated learning among nursing students. International Journal of Environmental Research and Public Health, 18(4), 1-9. https://doi.org/10.3390/ijerph18041738

Kusuma, I. cahya I., Noer, S. H., \& Caswita. (2020). Pengembangan PBM dengan Tahapan TPS untuk Meningkatkan Kemampuan Berpikir Reflektif Matematis dan Self-Efficacy Siswa. Jurnal Cendekia: Jurnal Pendidikan Matematika, 4(2), 870-885. https://doi.org/10.31004/cendekia.v4i2.321

Mulyani, E., Ratnaningsih, N., \& Sirri, E. L. (2020). Analisis Kesulitan Peserta Didik Dalam Menyelesaikan Soal Kemampuan Berpikir Reklektif Matematis Ditinjau Dari Tipe Kepribadian. Journal Of Authentic Research on Mathematics Education (JARME), 2(1), 4656.

Muzaimah, M., \& Noer, S. H. (2019). The analysis of student' reflective thinking skills in solving mathematical story problems on quadrilateral material. Regular Proceeding ISIMMED, 3, 2126.

Noer, S. H., Gunowibowo, P., \& Triana, M. (2020). Improving students' reflective thinking skills and self-efficacy through scientific learning. Journal of Physics: Conference Series, 1581(1), 1-9. https://doi.org/10.1088/1742-6596/1581/1/012036

Noviyanti, E. D., Purnomo, D., \& Kusumaningsih, W. (2021). Analisis Tingkat Kemampuan Berpikir Kreatif Dalam Pemecahan Masalah Matematika Ditinjau Dari Gaya Kognitif. Imajiner: Jurnal Matematika dan Pendidikan Matematika, 3(1), 57-68. https://doi.org/10.29100/jp2m.v4i1.1781

Öztürk, M. (2020). The Relationship between Self-Regulation and Proportional Reasoning: The Mediating Role of Reflective Thinking towards Problem Solving. TeEğitim VBilim, 45(204), 143-155. https://doi.org/10.15390/eb.2020.8480

Palanisamy, S., Bin, N., \& Nor, M. (2021). Effectiveness Of Mayer's Problem Solving Model With Visual Representation Teaching Strategy In Enhancing Year Four Pupils' Mathematical Problem Solving Ability. Malaysian Online Journal of Educational Sciences, 9(2), 41-52.

Permatasari, I., Noer, S. H., \& Gunowibowo, P. (2020). Efektivitas metode pembelajaran PQ4R ditinjau dari kemampuan berpikir reflektif matematis dan self-concept siswa. Pythagoras: Jurnal Pendidikan Matematika, 15(1), 61-72. https://doi.org/10.21831/pg.v15i1.33830

Rohmah, M., \& Sutiarso, S. (2018). Analysis Problem Solving in Mathematical Using Theory Newman. EURASIA Journal of Mathematics, Science and Technology Education, 14(2), 671681. https://doi.org/10.12973/ejmste/80630

Sari, N. H., Sutiarso, S., \& Dahlan, S. (2019). Analysis of students problem solving ability by using polya steps in linear program material. International Conference on Mathematics and Science Education, 4, 39-44.

Setiani, A., \& Lukman, H. S. (2020). Meningkatan Kemampuan Pemecahan Masalah Matematis Menggunakan Strategi Problem Based Learning Berbantuan Mind Mapping. PRISMA, 9(2), 
$128-135$.

Sihaloho, R., \& Zulkarnaen, R. (2019). Studi Kasus Kemampuan Berpikir Reflektif Matematis Siswa SMA. Prosiding Seminar Nasional Matematika dan Pendidikan Matematika, 3, 736-741.

Suryana, A., \& Nurrahmah, A. (2020). Guided Discovery Learning berbasis APOS: Alternatif Mengatasi Kesulitan Mahasiswa dalam Berpikir Reflektif Matematis. SINASIS 1 Prosiding Seminar Nasional Sains, 1(1), 361-372.

Syamsuddin, A. (2020). Identifikasi Kedalaman Berpikir Reflektif Calon Guru Matematika dalam Pemecahan Masalah Matematika melalui Taksonomi Berpikir Reflektif Berdasarkan Gaya Kognitif. Jurnal Elemen, 6(1), 128-145. https://doi.org/10.29408/jel.v6i1.1743

Thahir, A., Komarudin, Hasanah, U. N., \& Rahmahwaty. (2019). MURDER learning models and self efficacy: Impact on mathematical reflective thinking ability. Journal for the Education of Gifted Young Scientists, 7(4), 1120-1133. https://doi.org/10.17478/jegys.594709

Wahyuningtyas, P. S., Setiani, Y., \& Khaerunnisa, E. (2020). Pengaruh Model CORE dengan Pendekatan Open Ended terhadap Kemampuan Pemecahan Masalah Matematis Siswa SMP. Journal of Medives: Journal of Mathematics Education IKIP Veteran Semarang, 4(1), 81-96. https://doi.org/10.31331/medivesveteran.v4i1.979

Wijayanti, A. T., Caswita, \& Sutiarso, S. (2019). Pengembangan Lembar Kerja Peserta Didik (LKPD) Berbasis Masalah pada Pemecahan Konsep Matematis Siswa. Arithmetic : Academic Journal of Math, 101(1), 83-92.

Yasin, M., Fakhri, J., Siswadi, Faelasofi, R., Safi'i, A., Supriadi, N., Syazali, M., \& Wekke, I. S. (2020). The Effect of SSCS Learning Model on Reflective Thinking Skills and Problems Solving Ability. European Journal of Educational Research, 9(2), 743-752. https://doi.org/10.12973/eu-jer.9.2.743

Zahroh, S. H., Parno, \& Mufti, N. (2018). Keterampilan Pemecahan Masalah dengan Model Search, Solve, Create, and Share (SSCS) Problem Solving disertai Conceptual Problem Solving ( CPS ) pada Materi. Jurnal Pendidikan, 3(7), 968-973. 